\title{
Aqueous and nonaqueous lithium-air batteries enabled by water-stable lithium metal electrodes
}

\author{
Steven J. Visco • Vitaliy Y. Nimon • Alexei Petrov • Kirill Pridatko \\ Nikolay Goncharenko • Eugene Nimon • Lutgard De Jonghe \\ Yury M. Volfkovich • Daniil A. Bograchev
}

Received: 21 August 2013 /Revised: 3 February 2014 / Accepted: 10 February 2014 /Published online: 28 March 2014

(C) The Author(s) 2014. This article is published with open access at Springerlink.com

\begin{abstract}
The extremely high theoretical energy density of the lithium-oxygen couple makes it very attractive for nextgeneration battery development. However, there are a number of challenging technical hurdles that must be addressed for $\mathrm{Li}$ Air batteries to become a commercial reality. In this article, we demonstrate how the invention of water-stable, solid electrolyte-protected lithium electrodes solves many of these issues and paves the way for the development of aqueous and nonaqueous Li-Air batteries with unprecedented energy densities. We also show data for fully packaged Li-Air cells that achieve more than $800 \mathrm{Wh} / \mathrm{kg}$.
\end{abstract}

Keywords Lithium $\cdot$ Air $\cdot$ Battery $\cdot$ Solid electrolyte $\cdot$ LATP . Protected lithium electrode $\cdot$ PLE

$\begin{array}{ll}\text { Abbreviations } \\ c_{s} & \text { Concentration of species } s \\ c_{0, \mathrm{Lim}, s} & \text { Solubility limit of species } s \text { in free electrolyte } \\ c_{\mathrm{Lim}, s} & \text { Solubility limit of species } s \text { in a porous medium } \\ D_{s} & \text { Diffusion coefficient of species } s \\ D_{s, M}^{\mathrm{eff}} & \begin{array}{l}\text { Effective diffusion coefficient of species } s \text { in porous } \\ \text { medium } M\end{array} \\ F & \text { Faraday's constant } \\ H(x) & \text { Heaviside step function } \\ i_{0} & \text { Exchange current density } \\ J_{\mathrm{dep}, M} & \begin{array}{l}\text { Kinetic rate constant of product precipitation in } \\ \text { medium } M\end{array}\end{array}$

S. J. Visco • V. Y. Nimon $(\bowtie) \cdot$ A. Petrov $\cdot$ K. Pridatko

N. Goncharenko $\cdot$ E. Nimon $\cdot$ L. De Jonghe

PolyPlus Battery Company, 2431 5th Street, Berkeley,

CA 94710, USA

e-mail: vnimon@polyplus.com

Y. M. Volfkovich • D. A. Bograchev

Frumkin Institute of Physical Chemistry and Electrochemistry RAS,

Moscow, Russia

\begin{tabular}{|c|c|}
\hline$j^{\mathrm{Li}}$ & Volumetric reaction current \\
\hline$k$ & Conductivity of free electrolyte \\
\hline$k_{M}^{\mathrm{eff}}$ & $\begin{array}{l}\text { Effective conductivity of electrolyte in porous me- } \\
\text { dium } M\end{array}$ \\
\hline$k_{A}$ & Dissolution rate constant \\
\hline$K_{M}$ & Kinetic coefficient of precipitation \\
\hline$n_{\mathrm{Li}_{2} \mathrm{O}_{2}}$ & $\begin{array}{l}\text { Amount of discharge product formed during the } \\
\text { previous cycles }\end{array}$ \\
\hline$r_{\min }$ & Radius of the smallest pores filled with electrolyte \\
\hline$S$ & Specific surface density \\
\hline$t_{+}^{0}$ & Transference number for Li cations \\
\hline$t_{\text {char }}$ & Characteristic aging time \\
\hline$t_{\mathrm{c}}$ & End of the previous discharge cycle \\
\hline$T$ & Temperature \\
\hline$V_{s}$ & Molar volume of species $s$ \\
\hline$\alpha$ & Transfer coefficient \\
\hline$\alpha_{M}$ & Archie's exponent of medium $M$ \\
\hline$\gamma_{M}$ & $\begin{array}{l}\text { Difference between liquid electrolyte/pore wall and } \\
\text { discharge product/pore wall interface energies in } \\
\text { medium } M\end{array}$ \\
\hline$\varepsilon_{M}$ & Porosity of medium $M$ \\
\hline$\eta$ & Overpotential of reaction \\
\hline$\mu_{s}$ & Molar mass of species $s$ \\
\hline$\rho_{s}$ & Density of species $S$ \\
\hline & Electrolyte potential \\
\hline
\end{tabular}

\section{Introduction}

Galvanic couples based on the use of ambient oxygen offer significant gravimetric and volumetric advantages relative to conventional couples. Since the positive electrode $\left(\mathrm{O}_{2}\right)$ contributes no weight to the battery (prior to cell discharge), the theoretical energy density for metal-air couples, $\mathrm{M}+x \mathrm{O}_{2}=$ $\mathrm{MO}_{2 x}$, can be exceptionally high. Metal-air battery chemistry development has been based almost exclusively on the use of 
water-based electrolytes; certainly, all commercial zinc-air batteries use aqueous electrolyte. However, since $\mathrm{Zn}, \mathrm{Al}$, and $\mathrm{Fe}$ corrode rapidly at low $\mathrm{pH}$, aqueous electrolytes for metal-air cells use concentrated $\mathrm{KOH}$ to limit self-discharge. Unfortunately, once conventional aqueous metal-air cells are activated and oxygen is allowed to enter the cathode, $\mathrm{O}_{2}$ reacts directly with the zinc leading to relatively high self-discharge rates which limit the commercial markets available to $\mathrm{Zn}$-Air batteries. Another major problem with metal-air batteries using alkaline electrolytes is the tendency to absorb $\mathrm{CO}_{2}$ from ambient air which reacts with the $\mathrm{KOH}$ electrolyte to form poorly soluble $\mathrm{K}_{2} \mathrm{CO}_{3}$, a process known as carbonation, which degrades cell performance. Battery scientists have been aware of these problems for decades, but neither issue has been solved to date. The carbonation problem could be addressed by scrubbing $\mathrm{CO}_{2}$ from the ambient air stream, but this is impractical for most battery applications. When one considers replacement of the zinc anode with a lithium anode, the problem of self-discharge appears to be so untenable that this galvanic couple would seem to be unworthy of serious consideration. Notably, due to the invention of the waterstable protected lithium electrode, it now appears that the LiAir couple may be the only metal-air couple where selfdischarge can be completely eliminated.

Although the exceptionally high theoretical energy density for the lithium-oxygen couple has attracted the attention of battery scientists for decades, reactivity of lithium metal with atmospheric moisture has precluded practical development of this intriguing technology. The invention of the protected lithium electrode (PLE) by PolyPlus Battery Company has enabled the development of a new generation of lithium battery technologies utilizing electrolytes that would normally react with lithium metal. These unique protected electrodes are enabling for high energy density lithium-air and lithium-water batteries [1-5]. PLEs utilize waterstable, high $\mathrm{Li}^{+}$conductivity solid electrolytes to chemically isolate a lithium core from the external environment (described below). In this way, lithium electrodes can be used in combination with aqueous and aggressive nonaqueous electrolytes, a practical necessity for both lithium-air and lithium-water batteries.
There are several types of lithium-air technology $[6,7]$ which can be broadly divided by the choice of electrolyte, either aqueous or nonaqueous (Table 1). Although the choice of nonaqueous electrolyte allows the use of bare lithium foil, it also introduces a number of complex problems including the extremely low solubility of the cell reaction product, $\mathrm{Li}_{2} \mathrm{O}_{2}$, as well as reactivity of peroxide with most commonly used lithium battery electrolytes. For the case of nonaqueous Li-Air, most researchers use anhydrous oxygen to avoid corrosion of the bare Li electrode by ambient moisture. The use of bare unprotected lithium greatly limits the choice of electrolytes (due to reaction with lithium) and precludes the use of air due to rapid corrosion of the Li metal electrode by moisture. Some groups have reported ex situ passivation of lithium by carbonate electrolytes [8] or the use of oxidizing additives [9] like $\mathrm{LiNO}_{3}$ to form a protective solid electrolyte interface (SEI) allowing the use of aggressive solvents like amides and sulfoxides. Although it is unclear that this approach is fully protective or that the SEI will survive extended cycling, preliminary results are interesting. PolyPlus invented and patented water-stable PLEs [2, 4]. We described PLEs and lithium-air primary and rechargeable batteries based on them publicly for the first time in Nara, Japan [10-12]. The essential concept is to use a dense, pinhole-free $\mathrm{Li}^{+}$solid electrolyte to chemically isolate the lithium electrode $\left(\mathrm{Li}, \mathrm{Li}_{x} \mathrm{C}, \mathrm{Li}_{x} \mathrm{Si}\right.$, etc.) from the positive electrode (Fig. 1). The ceramic electrolyte most commonly used is based on the lithium analog of NASICON [13] with a composition of $\mathrm{Li}_{1+x+y}(\mathrm{M}, \mathrm{Al}, \mathrm{Ga})_{x} \quad\left(\mathrm{Ge}_{1-q} \mathrm{Ti}_{q}\right)_{2-}$ ${ }_{x} \mathrm{Si}_{y} \mathrm{P}_{3-y} \mathrm{O}_{12}$ and typically is of the composition $\mathrm{Li}_{1.3} \mathrm{Al}_{0.3} \mathrm{Ti}_{1.7}\left(\mathrm{PO}_{4}\right)_{3}$ (LATP) produced in Japan by Ohara Corporation and in the USA by Corning. Although lithium analogs of NASICON are stable to water, they are not stable to lithium, requiring the incorporation of an interlayer which can be solid state (i.e., $\mathrm{Li}_{3} \mathrm{~N}$ ), polymeric, ionic liquid, or nonaqueous liquid electrolyte. Some groups prefer to call this a "dual electrolyte" system, but it all dates back to original PLE concept and patents. This advance now appears to be critical to the practical development of both nonaqueous and aqueous lithium-air and lithiumsulfur batteries. The PLE also affords an elegant solution to the investigation and development of the air electrode for both aqueous and nonaqueous Li-Air chemistries.

Table 1 Lithium-air cell types

\begin{tabular}{|c|c|c|c|c|}
\hline Electrolyte & $\begin{array}{c}\text { Theoretical energy } \\
\text { density } \\
\text { (end of discharge) }\end{array}$ & Anode & Type & $\mathrm{OCV}$ \\
\hline \multirow{2}{*}{$\begin{array}{c}\text { Nonaqueous } \\
2 \mathrm{Li}+\mathrm{O}_{2}=\mathrm{Li}_{2} \mathrm{O}_{2}\end{array}$} & \multirow{2}{*}{$\begin{array}{c}3,450 \mathrm{Wh} / \mathrm{kg} \\
8,000 \mathrm{Wh} / 1\end{array}$} & $\begin{array}{l}\text { Unprotected } \\
\text { (bare Li) }\end{array}$ & Type A1 & \multirow[t]{2}{*}{$2.96 \mathrm{~V}$} \\
\hline & & Protected (PLE) & Type A2 & \\
\hline \multirow{2}{*}{$\begin{array}{c}\text { Aqueous } \\
4 \mathrm{Li}+\mathrm{O}_{2}+2 \mathrm{H}_{2} \mathrm{O}= \\
4 \mathrm{LiOH} \text { (simplified) }\end{array}$} & \multirow{2}{*}{$\begin{array}{c}3,850 \mathrm{Wh} / \mathrm{kg} \\
7,000 \mathrm{Wh} / 1\end{array}$} & $\begin{array}{l}\text { Unprotected } \\
\text { (bare Li) }\end{array}$ & $\begin{array}{c}\text { Not } \\
\text { possible }\end{array}$ & \multirow{2}{*}{$3.45 \mathrm{~V}$} \\
\hline & & Protected (PLE) & Type B & \\
\hline
\end{tabular}


Fig. 1 Schematic of protected lithium electrode

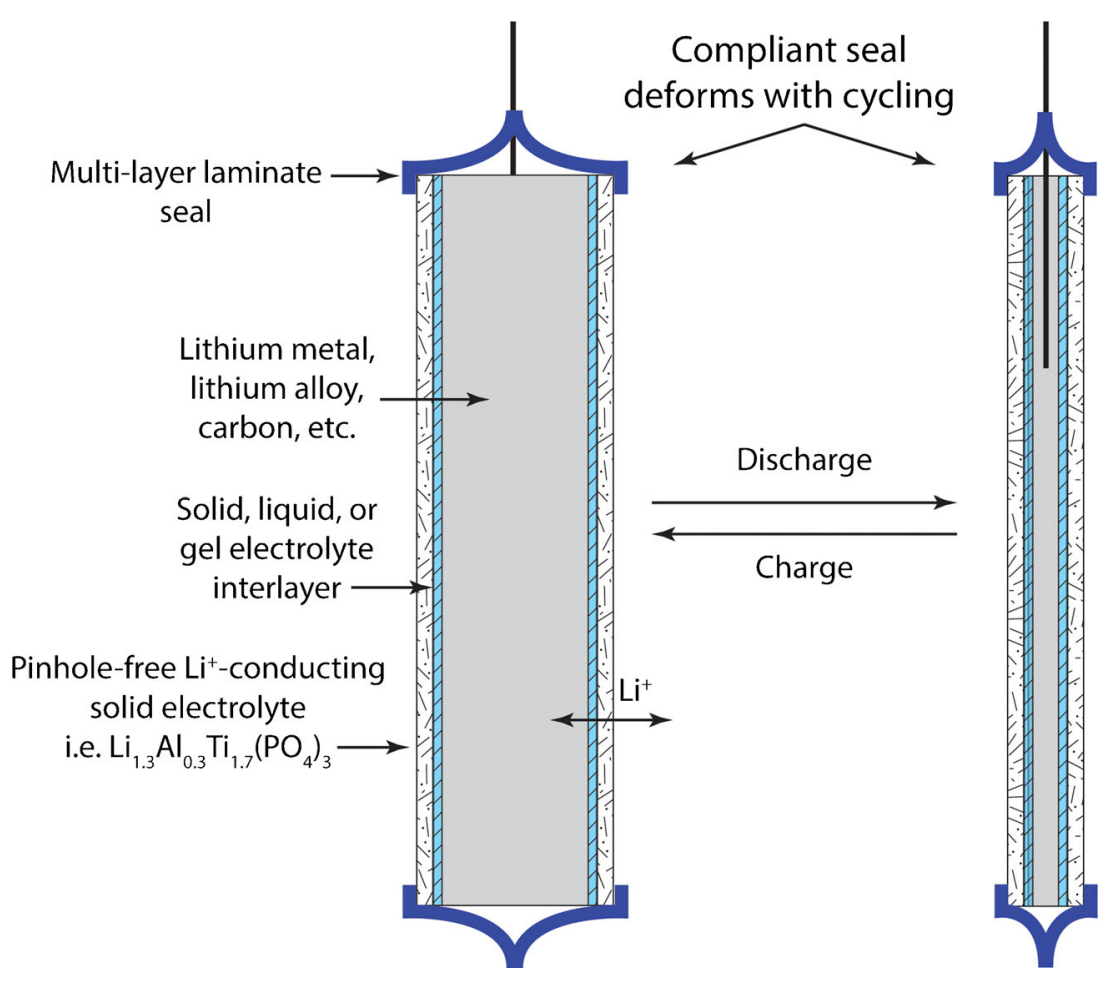

In conventional aqueous metal-air cells, the products of the cell reaction are contained in the anode; in zinc-air cells, the zinc suspension is converted to $\mathrm{ZnO}$ as the cell reaction proceeds, whereas the structure and composition of the air electrode are essentially unchanged as the cell is discharged. This is fundamentally different in lithium-air technology since the lithium anode cannot accommodate the product of cell reaction. In a Li-Air cell, the air electrode must facilitate oxygen reduction and evolution as well as accommodate a substantial amount of reaction product while still functioning as an air electrode throughout cell discharge. The engineering of such a structure is certainly nontrivial. Among the key differences between the nonaqueous and aqueous air electrodes is that for aqueous systems, this electrode functions as a gas diffusion electrode with hydrophobic domains creating channels for $\mathrm{O}_{2}$ gas transport, whereas in the nonaqueous case, the electrode is usually flooded. This fact highlights one of the key advantages of aqueous Li-Air over nonaqueous: the existence of three-phase boundaries throughout the aqueous air electrode leads to much faster oxygen transport and better electrode kinetics and therefore much higher sustained current densities. Another issue for the nonaqueous chemistry is solvent loss from the air electrode which would be unavoidable in an open system. Accordingly, any practical nonaqueous Li-Air battery would almost certainly need to be based on a closed system running on anhydrous oxygen, and such constraints may override the energy density advantages that Li-Air chemistry offers. Herein, we discuss some of the critical hurdles in lithium-air chemistry and our own progress in both aqueous and nonaqueous Li-Air systems.
PolyPlus has studied both the nonaqueous and aqueous LiAir chemistries in some detail to determine baseline performances for both approaches and to initiate commercialization of ultra lightweight rechargeable batteries. Assuming the use of commercially available components and reasonable values for components still in development, one can project Li-Air cell energy densities of about $1,000 \mathrm{Wh} / 1$ and $600 \mathrm{Wh} / \mathrm{kg}$ for a reversible electrode capacity of $5 \mathrm{mAh} / \mathrm{cm}^{2}$, implying that $\mathrm{Li}$ Air cells should sustain current densities of at least $1 \mathrm{~mA} / \mathrm{cm}^{2}$ $(\mathrm{C} / 5)$ in order to realize broad commercial application.

In the mid-2000s, interest in Li-Air batteries rose tremendously as a number of research groups claimed to be on the path to batteries with an order of magnitude improved energy density, motivated by the extremely high energy density of the $\mathrm{Li} / \mathrm{O}_{2}$ couple. If one does not include the weight of the oxygen consumed as the discharge reaction progresses, the specific energy for the $\mathrm{Li} / \mathrm{O}_{2}$ couple is $11,600 \mathrm{Wh} / \mathrm{kg}$. Although metalair batteries gain weight as the cell reaction progress and $\mathrm{O}_{2}$ is converted to lithium peroxide (yielding a theoretical maximum of $3,450 \mathrm{Wh} / \mathrm{kg}$ ), the average specific energy over the course of cell discharge is well over $7,000 \mathrm{Wh} / \mathrm{kg}$, approaching that of gasoline and providing ample motivation for cell developers.

The earliest work in nonaqueous Li-Air chemistry was reported by Abraham [14]. These studies were done with bare unprotected lithium, dry oxygen, and polymer electrolytes plasticized by organic carbonates. In fact, most early studies of nonaqueous Li-Air batteries relied heavily on the use of electrolytes based on organic carbonate solvents typically used in Li-ion batteries. 
However, an early paper by Aurbach and Yeager [15] pointed out that carbonate electrolytes are unstable to nucleophilic attack by superoxide anion radical $\left(\mathrm{O}_{2}^{-}\right)$, an intermediate in the reduction of oxygen. Consequently, early results that demonstrated extended cycling of $\mathrm{Li}-\mathrm{O}_{2}$ batteries and improvements due to electrocatalysts were greatly affected by solvent degradation and oxidation of those degradation products. Since that time, a number of groups have conducted careful investigations of those degradation phenomena $[16,17]$, followed by a search for stable nonaqueous electrolytes for $\mathrm{Li}_{-} \mathrm{O}_{2}$ batteries [18].

In 2005, PolyPlus Battery Company expanded the exploration of a number of nonaqueous Li-Air chemistries based on the use of PLEs in combination with solvents known to be stable to

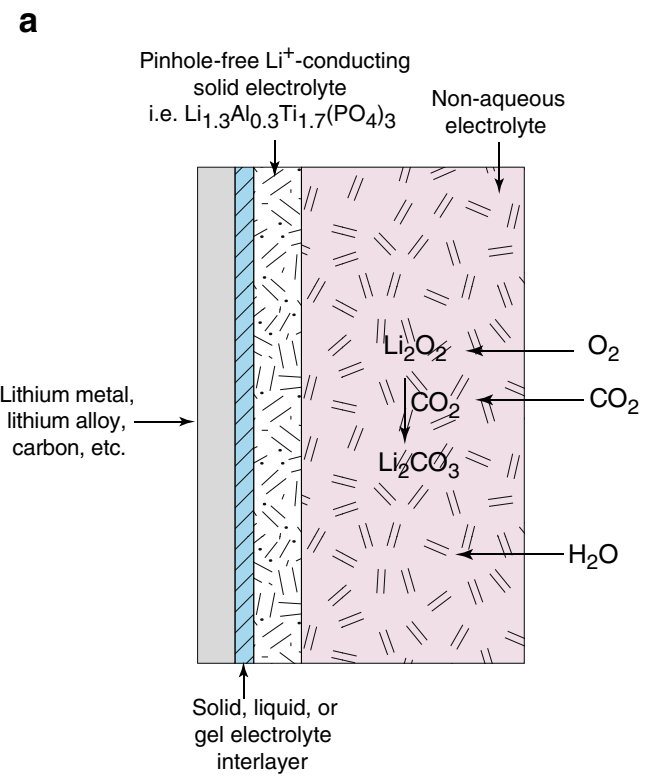

b

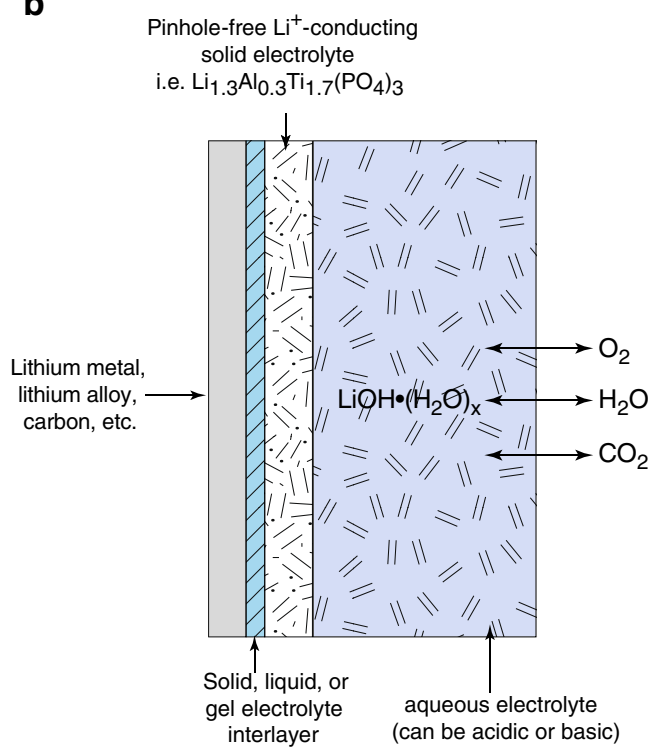

Fig. 2 Schematics of Li-Air cells employing PLE. a With nonaqueous electrolyte. b With aqueous electrolyte peroxide (and superoxide) but not necessarily to lithium metal including amides, sulfoxides, and nitriles [19]. A schematic drawing of nonaqueous Li-Air cells having a PLE is shown in Fig. 2a. Although the theoretical energy densities for Li-Air chemistries are certainly large (Table 1), practical cell performance will not exceed that of commercial Li-ion batteries until Li-Air cells reach certain threshold current densities and capacities. However, nonaqueous Li-Air performance is typically limited to very low current densities, often below $0.1 \mathrm{~mA} / \mathrm{cm}^{2}$, and cycled capacity is typically less than 1.0 to $1.5 \mathrm{mAh} / \mathrm{cm}^{2}$. Another concern for nonaqueous Li-Air technology is the irreversible and rapid reaction of lithium peroxide with carbon dioxide $\left[\mathrm{Li}_{2} \mathrm{O}_{2}(\mathrm{~s})+\mathrm{CO}_{2}=\mathrm{Li}_{2} \mathrm{CO}_{3}(\mathrm{~s})+1 / 2 \mathrm{O}_{2}\right]$. In fact, the NASA space program proposed the use of $\mathrm{Li}_{2} \mathrm{O}_{2}$ to scavenge $\mathrm{CO}_{2}$ in manned spaceflight operations [20].

The first examples of aqueous Li-Air batteries were reported by PolyPlus Battery Company [2, 10-12] enabled by the invention of the protected lithium electrode. One of the commonly recognized problems with aqueous metal-air chemistries is the high rate of self-discharge due to direct reaction of oxygen with the negative electrode. In stark contrast, the self-discharge rate of our aqueous Li-Air cell is effectively zero, due to the presence of a solid electrolyte membrane which chemically isolates the metal electrode from the positive electrode compartment (Fig. 2b). The use of a $\mathrm{Li}^{+}$-conductive solid electrolyte in aqueous electrolyte also begs the question of stability of the ceramic LATP as a function of $\mathrm{pH}$ (addressed below). As can be seen from the following, the performance of aqueous Li-Air cell technology, both primary and secondary, is quite promising.

\section{Experimental}

All operations for the preparation of nonaqueous electrolytes were performed in an MBraun glove box filled with Ar gas. Moisture and oxygen concentrations inside the glove box did not exceed $0.5 \mathrm{ppm}$. Solvents used for preparation of nonaqueous electrolytes, including dimethyl formamide (DMF), diglyme (DG), tetraglyme (TG), ethyl acetate (EA), and sulfolane, were obtained from Aldrich Chemicals and dried with $4 \AA$ molecular sieves. Tris(pentafluorophenyl)borane (TPFB) obtained from Aldrich Chemicals was used as received. Electrolyte salts including lithium bis(trifluoromethylsulfonyl)imide (LiTFSI), and $\mathrm{LiBF}_{4}$, were dried under vacuum at $120{ }^{\circ} \mathrm{C}$ for several days prior to electrolyte preparation. The moisture content in prepared nonaqueous electrolytes did not exceed 10 ppm except electrolytes containing TPFB, in which the moisture content was close to $60 \mathrm{ppm}$.

$\mathrm{Li}_{2} \mathrm{O}_{2}(99.9 \%$ purity) was obtained from Pfaltz \& Bauer Inc. $\mathrm{Li}_{2} \mathrm{O}_{2}$ was placed into two vials - the first one containing DMF and the second one containing 0.25 M TPFB in DMF. Both mixtures were stirred for 1 week, and undissolved solids were allowed to settle down. The clear fractions of the mixtures were 
removed with a syringe and then filtered using a Puradisc 25 Syringe Filter, $0.2 \mu \mathrm{m}$, obtained from GE Healthcare Life Sciences. The filtrates were sent to Maxxam Analytics (Canada) for lithium analysis. All chemicals used for preparation of aqueous electrolytes including $\mathrm{LiCl}, \mathrm{NH}_{4} \mathrm{Cl}, \mathrm{LiNO}_{3}, \mathrm{NH}_{4} \mathrm{NO}_{3}, \mathrm{LiOH}$, malonic acid, citric acid, and imidazole were obtained from Aldrich Chemicals and used as received. $\mathrm{H}_{3} \mathrm{PO}_{4}$ and $\mathrm{Na}_{2} \mathrm{HPO}_{4}$ used for preparation of buffer solutions were also obtained from Aldrich Chemicals.

PLEs for rechargeable batteries utilized lithium metal foil with a thickness of $120 \mu \mathrm{m}$ purchased from FMC Lithium. $\mathrm{Li}_{1+x+y}(\mathrm{M}, \mathrm{Al}, \mathrm{Ga})_{x}\left(\mathrm{Ge}_{1-q} \mathrm{Ti}_{\mathrm{q}}\right)_{2-x} \mathrm{Si}_{y} \mathrm{P}_{3-y} \mathrm{O}_{12}$ ceramic membranes (single ion, $\mathrm{Li}^{+}$, conductors) with conductivities in the range of 1.0 to $2.5 \times 10^{-4} \mathrm{~S} / \mathrm{cm}$ were obtained from Ohara Corporation in Japan and Corning Incorporated in the USA. Fully engineered high energy density primary Li-Air cells were based on double-sided PLEs as illustrated above and utilized ceramic membranes with a size of $50 \mathrm{~mm} \times 50 \mathrm{~mm}$. We designed single-sided test cells for electrochemical testing of electrolytes and electrode materials for secondary Li-Air batteries with nonaqueous and aqueous electrolytes. PLEs were assembled as described previously [19]. Stability of the solid electrolyte membranes in aqueous electrolytes was measured in situ by monitoring the impedance evolution over time.

Cells for impedance measurements employed an LATP membrane having an RF sputtered gold film with a thickness of 300$400 \mathrm{~nm}$ on one side and aqueous electrolyte on the other side. The surface area of gold electrodes used for impedance measurements was $1.3 \mathrm{~cm}^{2}$. A platinized platinum electrode served as a counter electrode (the impedance of the counter electrode did not contribute to the cell impedance due to the electrode's high surface area). The schematic of this cell is shown in Fig. 3a (insert). For comparison, we also obtained impedance spectra of an LATP membrane having sputtered gold films on both sides (Fig. 3b (insert)). The Li-Air test cells shown in Fig. 4 were built with a PLE utilizing $25.4 \mathrm{~mm} \times 25.4 \mathrm{~mm}$ ceramic membranes, a porous air cathode and a zirconia separator from Zircar Zirconia Inc. (USA). The air cathodes for all Li-Air cell configurations were prepared from an active mass containing Ketjenblack EC600JD carbon black, polytetrafluoroethylene (PTFE) dispersion, and a catalyst based on manganese oxide. Li-Air cells with nonaqueous electrolytes were tested in an atmosphere of dry oxygen. Li-Air cells with aqueous electrolytes were tested in air with controlled humidity. Experimental results related to testing of Li-Air cells with aqueous electrolytes were obtained at $50 \%$ relative humidity and $25{ }^{\circ} \mathrm{C}$. Constant temperature and humidity levels were maintained using CSZ's Z-Plus test chambers (Cincinnati Sub Zero Industrial). Electrochemical impedance measurements were performed in the frequency range from $10 \mathrm{~Hz}$ to $1.0 \mathrm{MHz}$ using a Solartron 1287 Electrochemical Interface and Solartron 1260 Impedance/gain-phase analyzer. A VMP-3 potentiostat/galvanostat from Bio-Logic (France) was used for linear sweep voltammetry experiments. Electrochemical
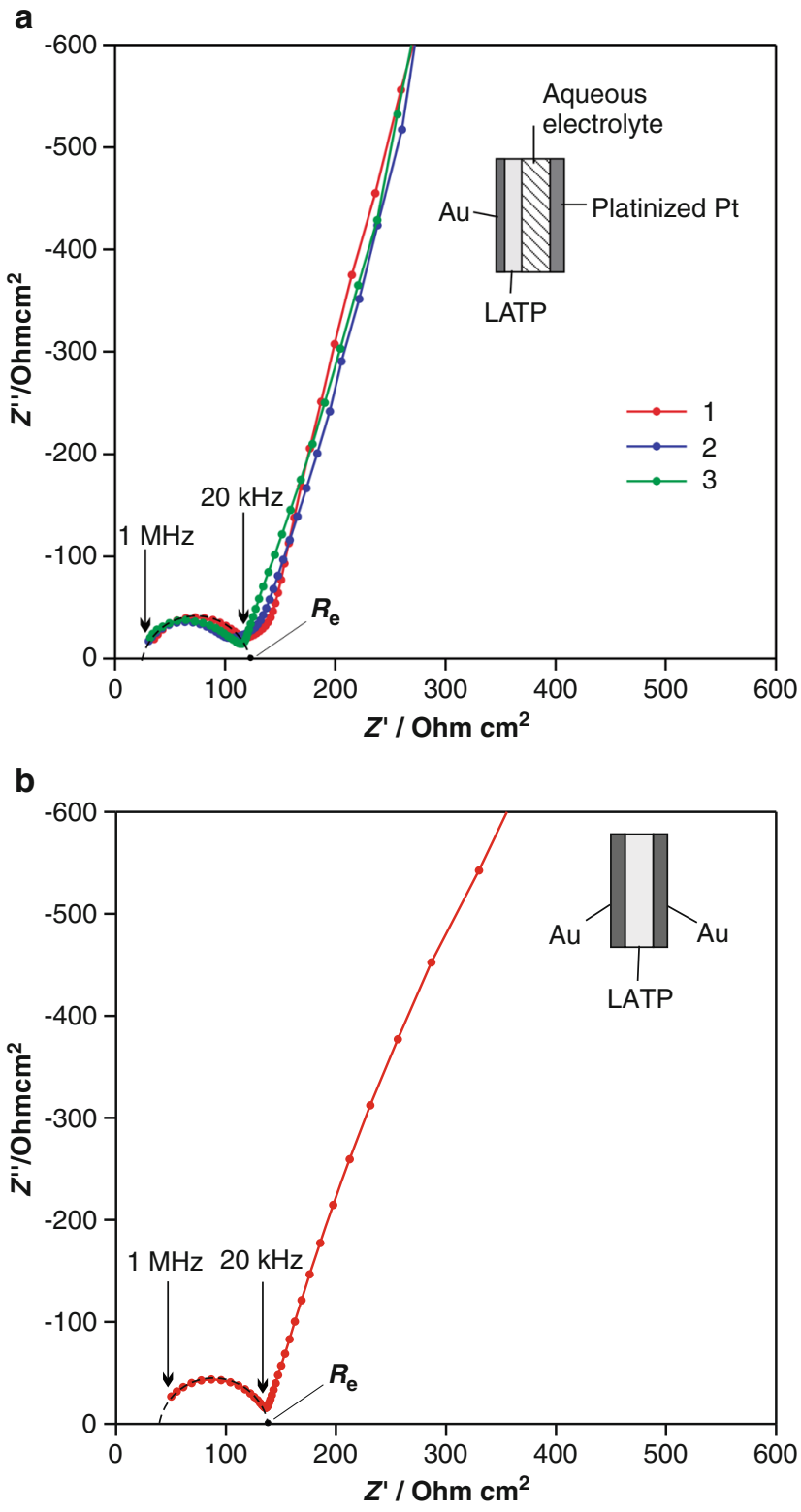

Fig. 3 a Impedance spectra for LATP membrane immersed in aqueous 4.0 $\mathrm{M} \mathrm{NH}_{4} \mathrm{Cl}+2.0 \mathrm{M} \mathrm{LiCl}$ electrolyte; 1-no storage, 2-57 days of storage, 3-632 days of storage. Membrane thickness is $125 \mu \mathrm{m}$. Insert shows the schematic of the impedance cell. Arrows indicate characteristic frequencies. b Impedance spectra for LATP membrane sandwiched between two gold electrodes. Membrane thickness is $152 \mu \mathrm{m}$. Insert shows the schematic of the impedance cell. Arrows indicate characteristic frequencies

discharge/charge testing of Li-Air cells was performed using a Maccor 4000 battery tester.

Concentrations of $\mathrm{Li}_{2} \mathrm{O}_{2}$ dissolved in nonaqueous electrolytes based on DMF were measured by inductively coupled plasma optical emission spectrometry at Maxxam Analytics. The lithium analysis was carried out using a PerkinElmer Optima 2000 DV spectrometer. Relative error in lithium concentration determination did not exceed $10 \%$. Obtained lithium concentrations were recalculated into concentrations of $\mathrm{Li}_{2} \mathrm{O}_{2}$. 


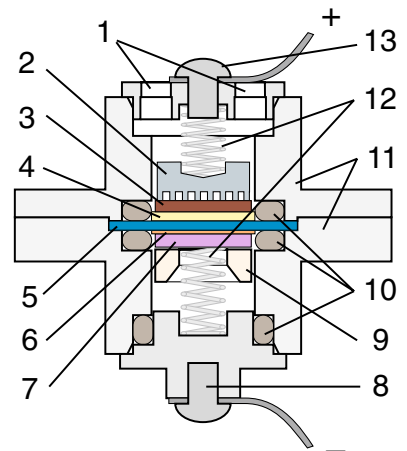

Fig. 4 Schematic of Li-Air test cell. 1-air access holes, 2 - cathode current collector, 3-air cathode, 4-separator/electrolyte reservoir, 5solid electrolyte membrane, 6-interlayer, 7-lithium foil, 8-anode terminal, 9 - anode holder, 10 - O-ring seals, 11 - plastic flanges, 12 compression springs, 13 - cathode terminal

During discharge of primary Li-Air cells with aqueous electrolyte, ammonia levels in test chambers were monitored with a NOVA-SensorElite Ammonia Gas Detector obtained from Aztec Signal. The $\mathrm{pH}$ values of aqueous electrolyte after partial and full discharge of primary Li-Air cells were determined with $\mathrm{BDH} \mathrm{pH}$ test strips from VWR.

\section{Results and discussion}

Nonaqueous Li-Air cells We studied the cycling behavior of Li-Air cells with electrolytes based on DMF. Bare lithium rapidly reacts with DMF; therefore, our Li-Air cells employed PLEs with LATP membranes. Electrochemical oxygen reduction in electrolytes based on DMF and tetraalkylammonium salts has been the subject of extensive research [21-23], and DMF was expected to be stable towards the products of oxygen reduction in Li-Air cells. Recently reported theoretical calculations of solvent reactivity [24] also confirm high stability of DMF against nucleophilic attack by superoxide.

One of the key problems with nonaqueous $\mathrm{Li}_{-} \mathrm{O}_{2}$ chemistry is the extremely low solubility of the discharge product, $\mathrm{Li}_{2} \mathrm{O}_{2}$. We explored increasing the solubility of $\mathrm{Li}_{2} \mathrm{O}_{2}$ in DMF by the addition of anion receptors to the nonaqueous electrolyte in an attempt to improve the performance of the air electrode. The use of anion receptors for enhancement of $\mathrm{Li}_{2} \mathrm{O}_{2}$ dissolution and improvement of electrolyte conductivity has been discussed in literature [25-27]. However, since anion receptors are incompatible with bare lithium metal, to the best of our knowledge, the effect of anion receptors on LiAir cell performance has never been actually tested. We performed such tests using Li-Air cells employing PLEs.

We had limited success with a commercially available anion receptor TPFB. Using ICP-OES analysis, it was found that $\mathrm{Li}_{2} \mathrm{O}_{2}$ solubility in DMF did not exceed $0.2 \mathrm{mmol} / \mathrm{L}$, while in the presence of $0.25 \mathrm{M}$ TPFB, it was close to $17 \mathrm{mmol} / \mathrm{L}$. This increase in solubility resulted in improved cyclability. As shown in Fig. 5a, we obtained several chargedischarge cycles in $\mathrm{Li}^{-} \mathrm{O}_{2}$ cells having a DMF-based electrolyte containing $0.25 \mathrm{M}$ TPFB. However, even in the presence of TPFB, capacity fade during cycling was observed. If after the first discharge the cell was stored under open circuit conditions, the capacity fade was even more pronounced (Fig. 5b).

Here, we propose that solid discharge product aging significantly contributes to the observed capacity fade during cycling. Although the morphology of $\mathrm{Li}_{2} \mathrm{O}_{2}$ particles formed during discharge of Li-Air cells with nonaqueous electrolyte has been studied [28, 29] (see review in [30]), to the best of our knowledge, the effect of $\mathrm{Li}_{2} \mathrm{O}_{2}$ precipitate aging has not been described in the literature. We modified the mathematical model presented in [31] to describe this effect. It was assumed that at the low charge current densities used in our experiments, the oxygen released during charge dissolved into the electrolyte and did not contribute to gas porosity.
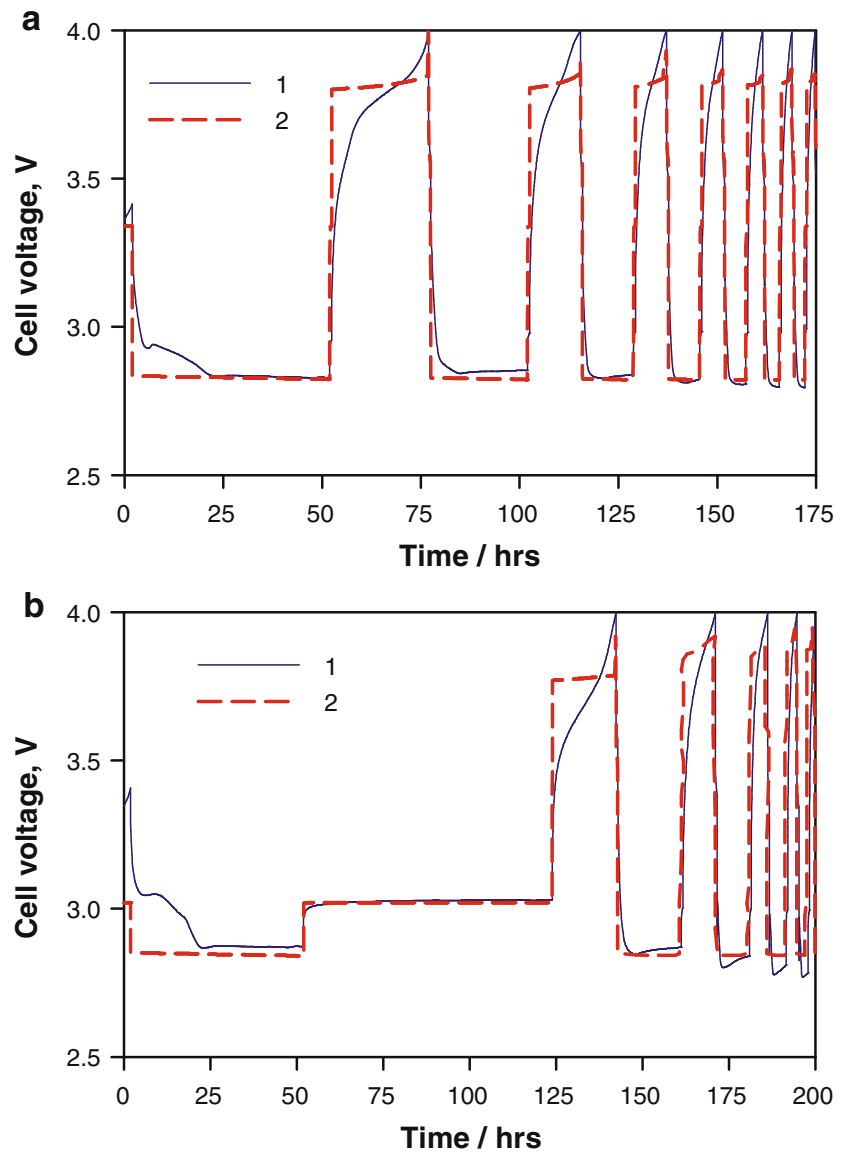

Fig. 5 Comparison of experimental ( 1 ) and calculated (2) cycling curves for Li-Air cells. Electrolyte: 0.5 M LiTFSI, 0.25 M TPFB in DMF. Discharge/ charge rate was $0.1 \mathrm{~mA} / \mathrm{cm}^{2}$. Charge cutoff voltage was $4.0 \mathrm{~V}$. a The first discharge lasted $50 \mathrm{~h}$; capacities of the second and the following discharges were equal to those of the charges immediately preceding them. $\mathbf{b}$ The first discharge lasted $50 \mathrm{~h}$ and was followed by $72 \mathrm{~h}$ of rest at open circuit; capacities of the second and the following discharges were equal to those of the charges immediately preceding them 
The model [31] was based on our experimental porosimetry data, which indicated that precipitation of the discharge product started in the small cathode pores (mesopores with radii less than $10 \mathrm{~nm}$ ). The equations describing mass and charge transport, reaction current, mass balance, and discharge product precipitation and dissolution are presented in Table 2. The modified model introduces the phenomenon of discharge product aging which manifests itself as a decrease in precipitate dissolution rate.

In this system, the aging process is unique since it happens within small mesopores, where it is influenced by interaction with pore walls. We have demonstrated that the order of discharge product deposition in the pores of different sizes depends on the surface properties of the carbon pore walldischarge product-liquid electrolyte system [31]. The discharge product aging also depends on the properties of this three-component system. In the literature, there are no theoretical models applicable to discharge product aging in such a complex system.

Equation (7) in Table 2 is the modified equation describing the rate of precipitation and dissolution of the discharge product. We assume that the rate of aging can be described with an exponential Eq. (8), where $t_{\text {char }}$ is the characteristic aging time, $t_{\mathrm{c}}$ is the end of the previous discharge cycle, $n_{\mathrm{Li}_{2} \mathrm{O}_{2}}$ is the amount of discharge product formed during the previous cycles, and $k_{A}$ is the dissolution rate constant.

Comparison of calculated and experimental cycling curves, both with and without rest (Fig. 5a, b), indicates that they are in satisfactory agreement. The experimental curves exhibit a gradual increase in voltage during charging; however, the calculated curves have a voltage plateau followed by a rapid increase in voltage.

The characteristic shape of the calculated curves is explained by the fact that in the model, the primary effect limiting the reaction is the decrease in concentration of dissolved $\mathrm{Li}_{2} \mathrm{O}_{2}$, resulting in a rapid rise in cathode overpotential to the 4-V limit, which corresponds to the end of charge. The gradual voltage increase observed in the experimental curves during charge is possibly related to side reactions resulting in the formation of lithium carbonate layer on the carbon air cathode surface [32].

The model predicts that at the end of each discharge, the volumetric fraction of solid discharge product increases from zero on the anode side of the electrolyte reservoir (separator) to a maximum at the cathode-air interface. This maximum volumetric fraction value increases with each charge-discharge cycle.

Values of the characteristic time for precipitate aging during each cycle were determined from the experimental cycling curves and are shown in Fig. 6. When the cycling procedure did not include a prolonged rest at open circuit, the characteristic time decreased rapidly with cycling until reaching its minimum value by the fourth cycle (Fig. 6a). For the cycling procedure with a 72-h rest after the first cycle, the minimum value was already reached by the second cycle (Fig. 6b).

The aging phenomenon can be explained by thermodynamically favorable coarsening of the solid discharge product $\left(\mathrm{Li}_{2} \mathrm{O}_{2}\right)$, which leads to a decrease in the precipitate's effective surface area and dissolution rate constant. Aging occurs both during cell rest and charge. Experimentally, the aging effect

Table 2 Summary of model equations

\begin{tabular}{|c|c|}
\hline Description & Model equation \\
\hline Effective diffusion coefficient for species $s$ in medium $M$ & $D_{M, s}^{\mathrm{eff}}=D_{s} \varepsilon^{\alpha_{M}}$ \\
\hline Effective diffusion equation for Li cations in medium $M$ & $\frac{\partial \varepsilon c_{\mathrm{Li}}}{\partial t}=\frac{\partial}{\partial x}\left(D_{M, \mathrm{Li}}^{\mathrm{eff}} \frac{\partial c_{\mathrm{Li}}}{\partial x}\right)-\frac{1-t_{+}^{0}}{F} j^{\mathrm{Li}}$ \\
\hline Effective diffusion equation for $\mathrm{O}_{2}$ in medium $M$ & $\frac{\partial \varepsilon c_{\mathrm{O}_{2}}}{\partial t}=\frac{\partial}{\partial x}\left(D_{M, O_{2}}^{\mathrm{eff}} \frac{\partial c_{\mathrm{O}_{2}}}{\partial x}\right)-\frac{j^{\mathrm{Li}}}{2 F}(3)$ \\
\hline Effective diffusion equation for $\mathrm{Li}_{2} \mathrm{O}_{2}$ in medium $M$ & $\frac{\partial \varepsilon c_{\mathrm{Li}_{2} \mathrm{O}_{2}}}{\partial t}=\frac{\partial}{\partial x}\left(D_{M, \mathrm{Li}_{2} \mathrm{O}_{2}}^{\mathrm{eff}} \frac{\partial c_{\mathrm{L}_{2} \mathrm{O}_{2}}}{\partial x}\right)+\frac{j^{\mathrm{Li}}}{2 F}-J_{\mathrm{dep}, M}$ \\
\hline Effective conductivity for medium $M$ & $k_{M}^{\mathrm{eff}}=k \varepsilon^{\alpha_{M}}$ \\
\hline Charge transport equation for medium $M$ & $\frac{\partial}{\partial x}\left(k_{M}^{\mathrm{eff}} \frac{\partial \varphi_{e}}{\partial x}\right)+j^{\mathrm{Li}}=0$ \\
\hline \multicolumn{2}{|l|}{ Rate of $\mathrm{Li}_{2} \mathrm{O}_{2}$ precipitation and dissolution } \\
\hline \multicolumn{2}{|l|}{$J_{\text {dep }}=K_{M}\left(H\left(c_{\mathrm{Li}_{2} \mathrm{O}_{2}}-c_{\mathrm{Lim}_{2} \mathrm{Li}_{2} \mathrm{O}_{2}}\right)-\theta H\left(c_{\mathrm{Lim}, \mathrm{Li}_{2} \mathrm{O}_{2}}-c_{\mathrm{Li}_{2} \mathrm{O}_{2}}\right)\right) \times\left(\frac{c_{\mathrm{Li}_{2} \mathrm{O}_{2}}}{c_{0, \mathrm{Lim}, \mathrm{Li}} \mathrm{O}_{2}}-\frac{c_{\mathrm{Lim}_{\mathrm{Li}} \mathrm{O}_{2}}}{c_{0, \mathrm{Lim}, \mathrm{Li}} \mathrm{O}_{2}}\right)^{2}$} \\
\hline Ratio of kinetic coefficients of dissolution and precipitation & $\theta=n_{\mathrm{Li}_{2} \mathrm{O}_{2}} k_{A} \exp \left(-\frac{t-t_{\mathrm{c}}}{t_{\text {char }}}\right)$ \\
\hline Kelvin equation & $\ln \left(\frac{c_{\mathrm{Lim}, \mathrm{Li}_{2} \mathrm{O}_{2}}}{c_{0, \mathrm{Lim}, \mathrm{Li}} \mathrm{L}_{2}}\right)=\frac{2 \gamma_{M} V_{\mathrm{Li}_{2} \mathrm{O}_{2}}}{r_{\min } R T}(9)$ \\
\hline Reaction current, Buttler-Volmer kinetics & $j^{\mathrm{Li}}=S i_{0}\left(\frac{c_{\mathrm{O}_{2}}}{c_{0, \mathrm{O}_{2}}} \exp \left(\frac{\alpha \eta F}{R T}\right)-\frac{c_{\mathrm{Li}_{2} \mathrm{O}_{2}}}{c_{0, \mathrm{~L}_{2} \mathrm{O}_{2}}} \exp \left(-\frac{(1-\alpha) \eta F}{R T}\right)\right)$ \\
\hline Local mass balance & $\frac{\partial \varepsilon}{\partial t}=-\frac{\mu_{\mathrm{Li}_{2} \mathrm{O}_{2}}}{\rho_{\mathrm{Li}_{2} \mathrm{O}_{2}}} J_{\mathrm{dep}, M}$ \\
\hline
\end{tabular}




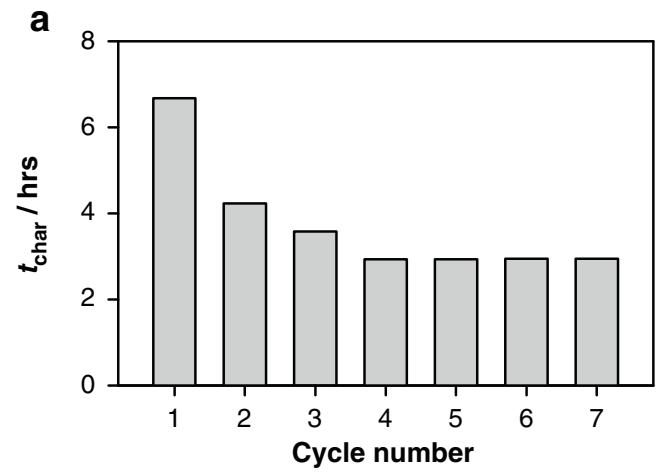

b

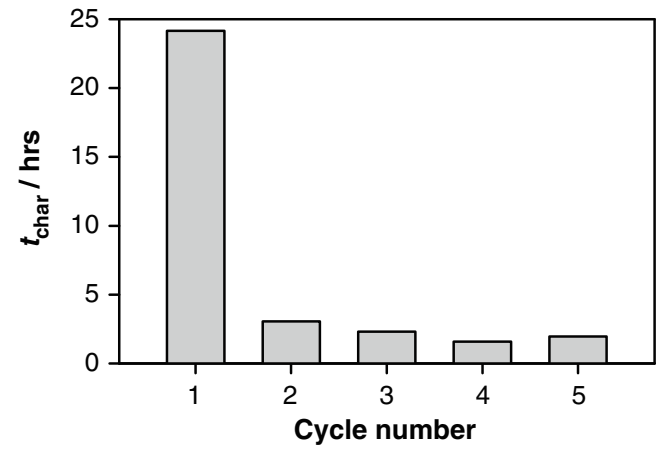

Fig. 6 Dependence of characteristic aging time on cycle number. a Testing procedure did not include a prolonged rest at open circuit. b Testing procedure included a $72-\mathrm{h}$ rest at open circuit after the first discharge

leads to a decrease of dissolved lithium peroxide during charging and a corresponding rise in air cathode polarization. It is possible that the aging phenomenon is even more complex and involves additional processes, such as formation of thin-resistive lithium carbonate layer on the carbon air cathode surface. Lithium carbonate could be produced via reaction of the precipitate with $\mathrm{CO}_{2}$ formed due to electrochemical oxidation of the solvent at high positive potentials or electrochemical oxidation of carbon air cathode surface [32].

In addition to studies of Li-Air cells having DMF electrolytes, we performed testing of lithium-air cells with glymebased electrolytes (diglyme and tetraglyme), as well as with electrolytes based on sulfolane.

Diglyme and tetraglyme were chosen due to their lower volatility compared to DME (monoglyme). Importantly, glymes are not sufficiently stable in contact with lithium metal, especially during cycling, which is why in all known battery systems, DME is used in combination with another cosolvent, such as dioxolane or an organic carbonate, which forms a stable SEI. Cycling performance of Li-Air cells with glyme electrolytes can be correctly evaluated only if a PLE is employed. Sulfolane (in combination with EA co-solvent and $\mathrm{LiBF}_{4}$ salt) was chosen because of its exceptional oxidative stability [33].

Cycling of nonaqueous lithium-air cells with glyme-based electrolytes is shown in Figs. 7 and 8. The cells exhibited a reversible capacity of slightly more than $1 \mathrm{mAh} / \mathrm{cm}^{2}$ at a

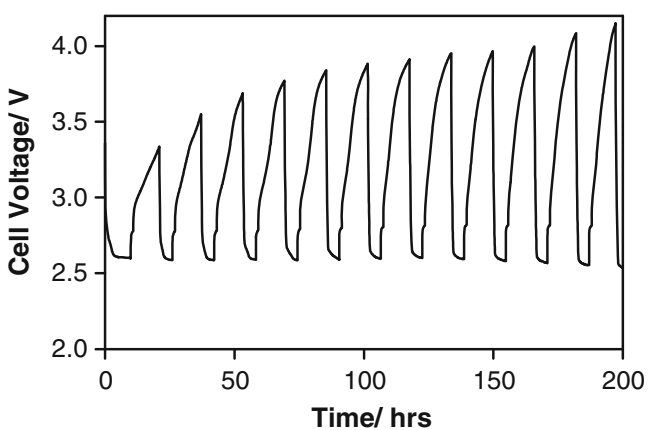

Fig. 7 Cycling performance of Li-Air cells. Electrolyte: 0.5 M LiTFSI in DG. Discharge rate was $0.25 \mathrm{~mA} / \mathrm{cm}^{2}$. Charge rate was $0.125 \mathrm{~mA} / \mathrm{cm}^{2}$. The first discharge lasted $10 \mathrm{~h}$. The first charge capacity was $50 \%$ of the first discharge capacity. Capacities of the second and the following discharges were equal to the capacities of the charges immediately preceding them or were limited by a cutoff voltage of $2.4 \mathrm{~V}$. Capacities of the second and the following charges were equal to the capacities of the discharges immediately preceding them or were limited by a cutoff voltage of $4.15 \mathrm{~V}$

discharge current density of $0.25 \mathrm{~mA} / \mathrm{cm}^{2}$. Although preliminary results with sulfolane (Fig. 9) are also interesting, we observed increasing polarization on charge and limited capacity on cycling. In order to achieve high specific energy and reasonable power density in an engineered battery, the lithium-air cells based on diglyme catholytes would require a fourfold improvement in reversible capacity at four times the current density shown here. Recently, several other groups have reported encouraging cycling of the $\mathrm{O}_{2}$ electrode in nonaqueous electrolytes based on organic solvents such as sulfoxides [8, 34] and amides [9]; neither of which is stable to bare metallic lithium metal. Assuming that developers are successful in identifying nonaqueous electrolytes that permit reversible cycling of oxygen electrode, it appears likely practical cells will require a fully protected lithium electrode (an absolute for aqueous Li-Air). Still, even with the incorporation of a PLE, there are unresolved technical issues for nonaqueous lithium air including (1) evaporation of nonaqueous solvent

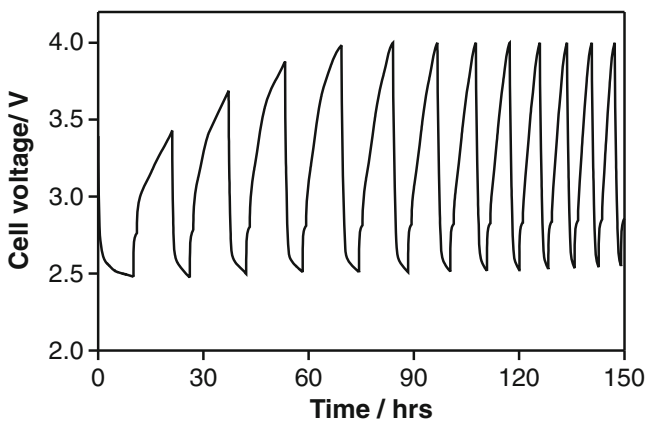

Fig. 8 Cycling performance of Li-Air cells. Electrolyte: 0.5 M LiTFSI in TG. Discharge rate was $0.25 \mathrm{~mA} / \mathrm{cm}^{2}$. Charge rate was $0.125 \mathrm{~mA} / \mathrm{cm}^{2}$. The first discharge lasted $10 \mathrm{~h}$. The first charge capacity was $50 \%$ of the first discharge capacity. Capacities of the second and the following discharges were equal to the capacities of the charges immediately preceding them or were limited by a cutoff voltage of $2.4 \mathrm{~V}$. Capacities of the second and the following charges were equal to the capacities of the discharges immediately preceding them or were limited by a cutoff voltage of $4.0 \mathrm{~V}$ 


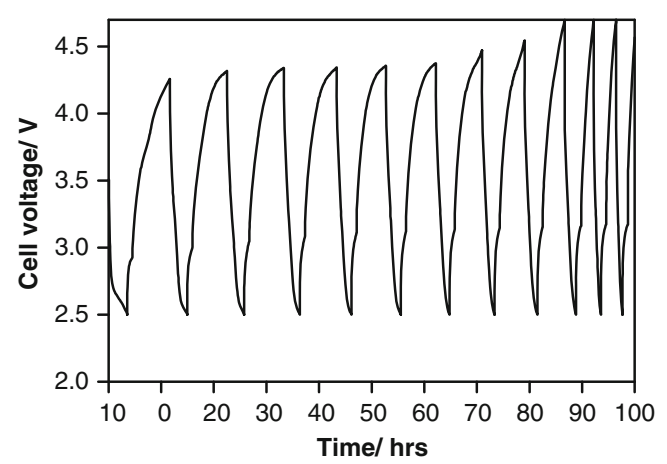

Fig. 9 Cycling performance of Li-Air cells. Electrolyte: $0.5 \mathrm{M} \mathrm{LiBF}_{4}$ in sulfolane and EA mixture (1 to 1 by volume). Discharge rate was $0.25 \mathrm{~mA} / \mathrm{cm}^{2}$. Charge rate was $0.125 \mathrm{~mA} / \mathrm{cm}^{2}$. All discharge capacities were limited by a cutoff voltage of $2.5 \mathrm{~V}$. All charge capacities were equal to the capacities of the discharges immediately preceding them or were limited by a cutoff voltage of $4.7 \mathrm{~V}$

from the air electrode to the external environment; (2) uptake of water by the nonaqueous electrolyte; (3) irreversible reaction of $\mathrm{Li}_{2} \mathrm{O}_{2}$ with $\mathrm{CO}_{2}$ leading to the formation of $\mathrm{Li}_{2} \mathrm{CO}_{3}$ and loss of electrode capacity; (4) flooding of the air electrode with nonaqueous electrolyte leading to slow oxygen transport; and (5) precipitation of insoluble $\mathrm{Li}_{2} \mathrm{O}_{2}$ in the pores of the air electrode leading to pore clogging and polarization of the air electrode. Some of the technical issues for nonaqueous Li-Air could be addressed with a closed system (no solvent loss) and anhydrous oxygen (no water or $\mathrm{CO}_{2}$ contamination), although this approach would certainly degrade the system energy density. Assuming successful identification of a nonaqueous electrolyte stable to products of $\mathrm{O}_{2}$ reduction and the use of a closed system with dry oxygen, there still remains the issue of poor solubility of $\mathrm{Li}_{2} \mathrm{O}_{2}$, flooding of the air electrode leading to poor electrode kinetics, and clogging of the porous oxygen electrode structure as cell discharge proceeds. In light of the above discussion, the list of promising electrolyte solvents for nonaqueous Li-Air batteries is relatively short at this time including amides, sulfoxides, and glymes, as described in a PolyPlus patent application in early 2006 [19]. To date, none of these electrolytes demonstrate the rate capability, cycling capacity $\left(\mathrm{mAh} / \mathrm{cm}^{2}\right)$, or cycle life required for practical application.

Aqueous Li-Air cells Determination of stability of the ceramic membrane in aqueous electrolyte is not trivial and is certainly not measured properly by immersing the membrane into a large volume of concentrated acid or base. PolyPlus has determined the stability of the LATP ceramic membrane in a variety of aqueous electrolytes by in situ impedance spectroscopy using a volume of electrolyte corresponding closely to that used in a practical cell. There is no doubt that LATP membranes degrade in strong inorganic acid or base, particularly when there is a large excess of aqueous electrolyte, but this has little to do with realistic cell conditions. We have found that LATP membranes exhibit satisfactory stability, depending critically on the composition of the electrolyte, $\mathrm{pH}$, and nature and concentration of the supporting salts. Our primary Li-Air cells utilize electrolytes based on $\mathrm{NH}_{4} \mathrm{Cl} / \mathrm{LiCl}$ and $\mathrm{NH}_{4} \mathrm{NO}_{3} / \mathrm{LiNO}_{3}$. These electrolyte blends have the advantage of generating hygroscopic $\mathrm{LiCl}$ or $\mathrm{LiNO}_{3}$ on cell discharge which scavenges $\mathrm{H}_{2} \mathrm{O}$ from the external environment, alleviating the need to carry a stoichiometric quantity of water for the cell reaction. Since these electrolytes are slightly acidic prior to cell discharge, there is no uptake of $\mathrm{CO}_{2}$ on exposure to ambient atmosphere. For rechargeable LiAir cells, PolyPlus developed polyprotic organic acid-based electrolytes. Some of these polyprotic acids were found to degrade the performance of the LATP membranes as evidenced by a significant increase in the impedance arc corresponding to the total resistance of the membrane. Fortunately, we identified several polyprotic acid electrolytes in which LATP membranes exhibited excellent stability over time.

Primary aqueous Li-Air Lithium-air batteries share some common features with primary Zn-Air batteries including the use of a gas diffusion electrode for oxygen reduction. As discussed above, in a Li-Air battery, the products of cell discharge are stored in the air electrode which means that the cathode compartment must accommodate a large volume of solid reaction product. Our air electrode design can accommodate a tremendous amount of solid discharge product as demonstrated by the data shown in Fig. 10. We have designed and fabricated Li-Air cells with PLEs of approximately $10 \mathrm{Ah}$ based on $50 \mathrm{~mm} \times 50 \mathrm{~mm}$ solid electrolyte membranes and thick lithium foils (total thickness of approximately $2.5 \mathrm{~mm}$ ). In these cells, the lithium capacity is matched with two air electrodes (filled with $6.8 \mathrm{ml}$ of aqueous electrolyte each) and exposed to air. At a current density of $0.5 \mathrm{~mA} / \mathrm{cm}^{2}$, these air electrodes deliver an area-specific capacity of approximately $200 \mathrm{mAh} / \mathrm{cm}^{2}$ (for a total capacity of 8,500 mAh) at an energy density of more than $600 \mathrm{Wh} / \mathrm{kg}$ for fully engineered cells. The cells tested at a current density of $0.3 \mathrm{~mA} / \mathrm{cm}^{2}$ delivered a

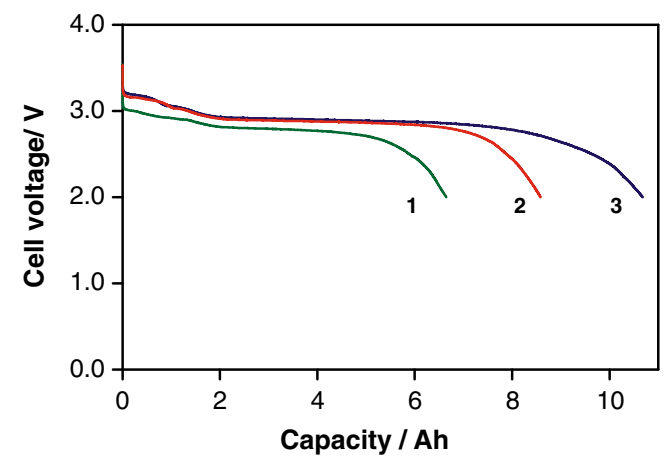

Fig. 10 Discharge of fully engineered primary Li-Air cells with aqueous electrolyte comprising $2 \mathrm{M} \mathrm{LiCl}$ and $4 \mathrm{M} \mathrm{NH}_{4} \mathrm{Cl}$. Discharge rate: 1 $1.0 \mathrm{~mA} / \mathrm{cm}^{2}, 2-0.5 \mathrm{~mA} / \mathrm{cm}^{2}, 3-0.3 \mathrm{~mA} / \mathrm{cm}^{2}$ 
massive specific energy of $800 \mathrm{Wh} / \mathrm{kg}$; to the best of our knowledge, this is the highest specific energy ever reported for an electrochemical device (other than PolyPlus Li-water battery).

LATP membranes demonstrated excellent stability in $\mathrm{NH}_{4} \mathrm{Cl} / \mathrm{LiCl}$ and $\mathrm{NH}_{4} \mathrm{NO}_{3} / \mathrm{LiNO}_{3}$ electrolytes employed in primary Li-Air cells. In Fig. 3a, we present the impedance spectra of an LATP membrane immersed in $\mathrm{NH}_{4} \mathrm{Cl} / \mathrm{LiCl}$ aqueous electrolyte after various periods of storage. In order to interpret the shape of impedance diagram in Fig. 3a, we also obtained impedance spectra for a LATP membrane sandwiched between sputtered gold electrodes (Fig. 3b). Similar impedance diagrams for LATP membranes having an ionically blocking inert electrode on each side have been previously reported by other groups and are widely used to determine the ionic conductivity of LATP membranes [35-37]. Equivalent circuits proposed in the literature for impedance of solid-state cells employing LATP membranes can be quite complex and usually include at least one constant phase impedance element $[38,39]$. The low-frequency intercept with the $x$ axis corresponds to the total active resistance of the LATP membrane $R_{\mathrm{e}}$, which includes resistances of both grain boundaries and grains of polycrystalline LATP membranes. In our case, the ionic conductivity calculated from the value of $R_{\mathrm{e}}$ is $1.1 \times 10^{-4} \mathrm{~S} / \mathrm{cm}$. Since LATP membranes in commercial Li-Air cells may be exposed to $\mathrm{NH}_{4} \mathrm{Cl} / \mathrm{LiCl}$ aqueous electrolyte for extended periods of time during storage, we determined the evolution of the impedance response over time. As seen in Fig. 3a, b, the impedance diagrams for the cell, where the ceramic LATP membrane is immersed in liquid electrolyte and the cell where the membrane is sandwiched between two gold electrodes, are almost identical, and the shape of the impedance plot in Fig. 3a exhibits negligible changes during storage of up to 21 months. In fact, the value of resistance $R_{\mathrm{e}}$ of the LATP membrane was determined from the low-frequency intercept with the $x$ axis changes less than $10 \%$ in 21 months of storage.

We calculated the LATP membrane's ionic conductivity from the low-frequency intercept $R_{\mathrm{e}}$ in Fig. 3a and the membrane thickness, and this conductivity value is very close to that obtained from the data in Fig. 3b. Therefore, the replacement of one of the gold electrodes with liquid electrolyte did not affect the membrane resistance during 21 months of storage and did not generate new features on the impedance spectra.

The fact that the value of membrane resistance $R_{\mathrm{e}}$ remains practically constant during long-term storage is strong evidence that the LATP membrane is chemically stable to the aqueous electrolyte employed in the cell.

One of the key features of the PLE is that it de-couples the lithium electrode from the air electrode environment allowing complex tailoring of the aqueous electrolyte to enhance Li-Air performance. This is illustrated definitively through the use of aqueous $\mathrm{NH}_{4} \mathrm{Cl}$ electrolyte which on Li-Air cell discharge liberates highly hygroscopic $\mathrm{LiCl}$ into the air electrode which then scavenges $\mathrm{H}_{2} \mathrm{O}$ from ambient air [40-42]. As the Li-Air cell is discharged, a fairly complex reaction ${ }^{1}$ takes place which can be viewed in its simplest case as such:

$2 \mathrm{Li}+2 \mathrm{NH}_{4} \mathrm{Cl}+1 / 2 \mathrm{O}_{2} \rightarrow 2 \mathrm{NH}_{3} \uparrow+\mathrm{H}_{2} \mathrm{O}+2 \mathrm{LiCl}$

$2 \mathrm{Li}+1 / 2 \mathrm{O}_{2}+\mathrm{H}_{2} \mathrm{O} \rightarrow 2 \mathrm{LiOH}$

As one can see from the data for aqueous Li-Air cells shown in Fig. 10, the discharge curves exhibit two typical regions: the initial discharge where the voltage decreases linearly and then a long plateau where most of the capacity is delivered. An ammonia gas detector placed in the environmental chamber, where the cells were being discharged, confirmed $\mathrm{NH}_{3}$ gas evolution during the initial stage of discharge corresponding to the first region on the discharge curves. We performed post-mortem analysis of cells at various stages of discharge and measured the $\mathrm{pH}$ of cell electrolyte. We found that during the first stage of discharge, the $\mathrm{pH}$ of cell electrolyte rapidly increased from 4.5 to approximately 8.5 and then slowly increased to approximately 9.5 , which is in good agreement with reaction (1). Since $\mathrm{NH}_{3}$ and $\mathrm{NH}_{4} \mathrm{Cl}$ dissolved in water form an ammonia buffer solution, the electrolyte $\mathrm{pH}$ stabilizes at a value below 10 . According to reaction (2), when all $\mathrm{NH}_{4} \mathrm{Cl}$ in battery electrolyte is converted to $\mathrm{LiCl}$ and $\mathrm{NH}_{3}$, further discharge should lead to the formation of $\mathrm{LiOH}$ and a significant increase in electrolyte $\mathrm{pH}$. Post-mortem analysis of cells at the second stage of discharge corresponding to the plateau region on the discharge curve indicated the presence of a solid discharge product and an increase in $\mathrm{pH}$ to a value greater than 13. These findings are in good agreement with reaction (2). For our cells, the major fraction (80-85\%) of discharge capacity was delivered in the two-phase (solidliquid) region, corresponding to the long plateau on the discharge curves.

Since the first stage of discharge involves conversion of $\mathrm{NH}_{4} \mathrm{Cl}$ to hygroscopic $\mathrm{LiCl}$, the initial amount of water loaded into the cell prior to discharge can be significantly less than the amount of water required for a full discharge. The process of bringing water into the cathode is also affected by the presence of other species in solution. The rate at which water is scavenged from the external atmosphere is determined by a number of variables including depth of discharge, distribution and morphology of the $\mathrm{LiOH}$ and $\mathrm{LiCl}$ hydrates (and/or complexes formed on cell discharge), structure and composition of the porous air electrode, and the water permeability of the gas diffusion membrane. All of these factors must be

\footnotetext{
${ }^{1}$ It is likely that a distribution of $\mathrm{LiOH}$ and $\mathrm{LiCl}$ hydrates and/or complexes is formed on cell discharge; the presence of the intermediate $\mathrm{Li}_{2} \mathrm{O}_{2}$ solid product is also possible.
} 


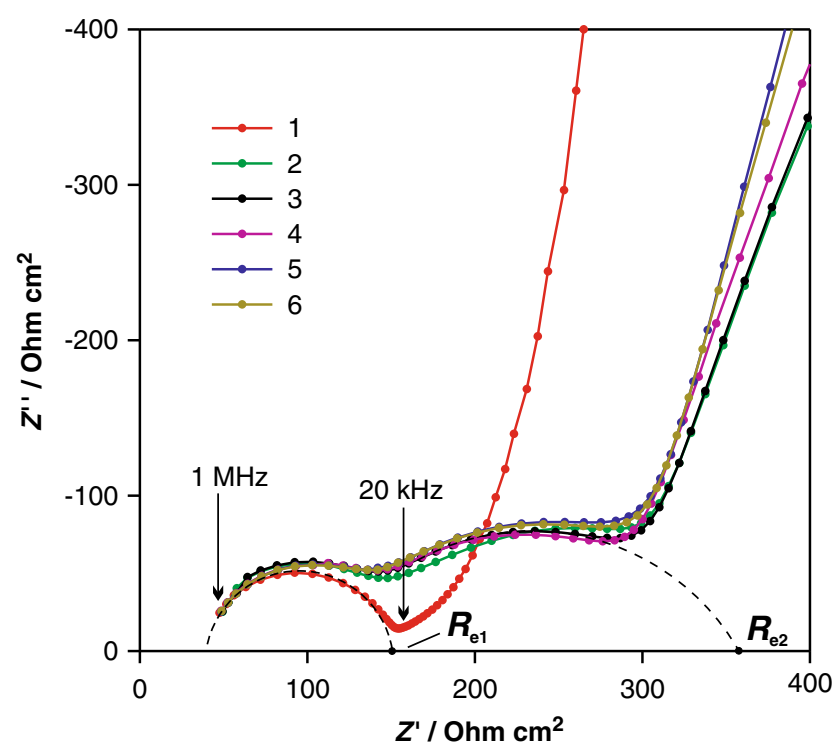

Fig. 11 Impedance spectra for LATP membrane exposed to $2.0 \mathrm{M}$ citric acid electrolyte. Membrane thickness is $160 \mu \mathrm{m}$. Length of exposure: $1-$ less than 1 day, $2-4$ days, 3-10 days, 4-13 days, 5-20 days, $6-$ 21 days. Arrows indicate characteristic frequencies

considered when designing an air electrode for particular applications, since the Li-Air cell behavior (power and capacity) will be affected by the external environment.

Rechargeable aqueous Li-Air Although we have demonstrated superb specific energy for primary Li-Air cells using aqueous $\mathrm{NH}_{4} \mathrm{Cl} / \mathrm{LiCl}$ electrolytes, these electrolytes are not appropriate for secondary cells (partly due to the formation of $\mathrm{NH}_{3}$ during discharge). We have explored a number of polyprotic acids for use in secondary Li-Air cells. The use of polyprotic acid delays generation of insoluble discharge products and allows rejection of $\mathrm{CO}_{2}$ at high states of cell charge. In general, strong inorganic acids are poor choices since they attack the LATP membranes and in some cases the corresponding salts are practically insoluble in water (e.g., $\left.\mathrm{Li}_{3} \mathrm{PO}_{4}\right)$ leading to rapid precipitation on discharge and/or limited reversibility. Accordingly, PolyPlus uses polyprotic organic acids in its rechargeable Li-Air cells [43]. Two such electrolytes are based on citric and malonic acids.

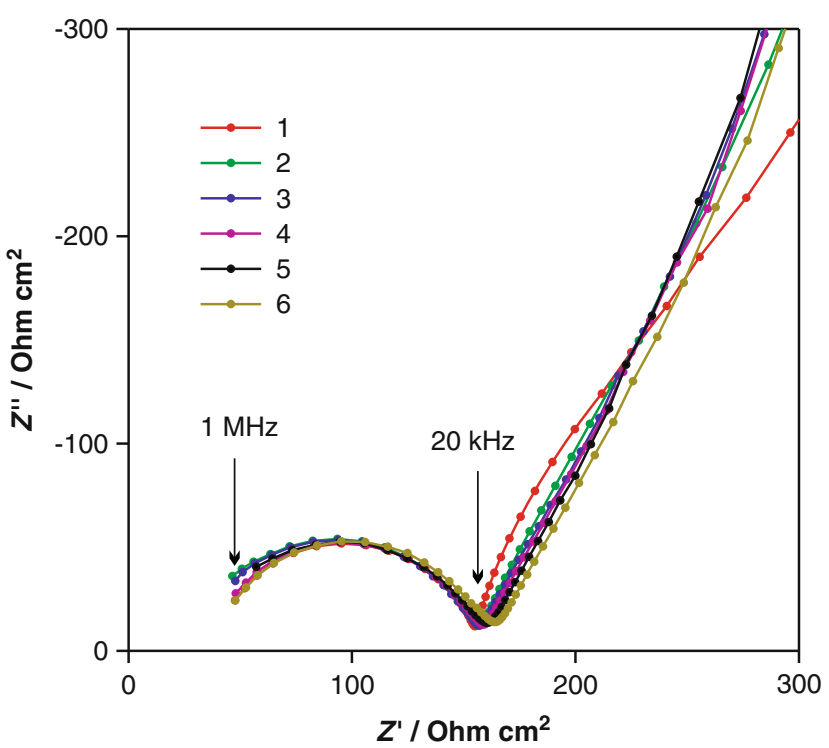

Fig. 13 Beneficial effect of imidazole on the impedance behavior of LATP exposed to citric acid. Membrane thickness is $150 \mu \mathrm{m}$. Length of exposure: $1-$ less than 1 day, $2-4$ days, 3-5 days, 4-6 days, 511 days, 6-13 days. Arrows indicate characteristic frequencies

The Li-Air cell reactions for malonic and citric acid electrolytes are shown below.

Malonic acid

Anode:

$\mathrm{Li} \rightarrow \mathrm{Li}^{+}+\mathrm{e}^{-}$

Cathode:

$4 \mathrm{H}_{2} \mathrm{C}_{3} \mathrm{H}_{2} \mathrm{O}_{4}+\mathrm{O}_{2}+4 \mathrm{e}^{-} \rightarrow 4 \mathrm{HC}_{3} \mathrm{H}_{2} \mathrm{O}_{4}^{-}+2 \mathrm{H}_{2} \mathrm{O}$

$4 \mathrm{HC}_{3} \mathrm{H}_{2} \mathrm{O}_{4}^{-}+\mathrm{O}_{2}+4 \mathrm{e}^{-} \rightarrow 4 \mathrm{C}_{3} \mathrm{H}_{2} \mathrm{O}_{4}^{2-}+2 \mathrm{H}_{2} \mathrm{O}$

Citric acid

Anode:

$\mathrm{Li} \rightarrow \mathrm{Li}^{+}+\mathrm{e}^{-}$
Fig. 12 Acid-base reaction of citric acid and imidazole<smiles>O=C(O)CC(O)(CC(=O)O)C(=O)O</smiles>

Citric Acid<smiles>Cc1cnc[nH]1</smiles>

Imidazole<smiles>O=C(O)CC(O)(CC(=O)O)C(=O)O</smiles>

Imidazolium Dihydrogen Citrate 
Cathode:

$4 \mathrm{H}_{3} \mathrm{C}_{6} \mathrm{H}_{5} \mathrm{O}_{7}+\mathrm{O}_{2}+4 \mathrm{e}^{-} \rightarrow 4 \mathrm{H}_{2} \mathrm{C}_{6} \mathrm{H}_{5} \mathrm{O}_{7}^{-}+2 \mathrm{H}_{2} \mathrm{O}$

$4 \mathrm{H}_{2} \mathrm{C}_{6} \mathrm{H}_{5} \mathrm{O}_{7}^{-}+\mathrm{O}_{2}+4 \mathrm{e}^{-} \rightarrow 4 \mathrm{HC}_{6} \mathrm{H}_{5} \mathrm{O}_{7}^{2-}+2 \mathrm{H}_{2} \mathrm{O}$

$4 \mathrm{HC}_{6} \mathrm{H}_{5} \mathrm{O}_{7}^{2-}+\mathrm{O}_{2}+4 \mathrm{e}^{-} \rightarrow 4 \mathrm{C}_{6} \mathrm{H}_{5} \mathrm{O}_{7}^{3-}+2 \mathrm{H}_{2} \mathrm{O}$

The nature of the polyprotic organic acid has a large impact on the stability of the solid electrolyte membrane; for the case of the electrolyte based on diprotic malonic acid, we did not observe impedance rise for the exposed LATP membrane. However, for some polyprotic organic acids including citric acid, LATP membranes do show evidence of degradation on storage manifesting itself as formation of resistive layers on the membrane surface. Stability of LATP solid electrolyte membranes in citric acid is shown in Fig. 11. We observed a rise in the active resistance of the membrane from its initial value of $\left.R_{\mathrm{e} 1}(153 \mathrm{Ohm} \mathrm{cm})^{2}\right)$ to a significantly higher value of $R_{\mathrm{e} 2}$, which stabilized at over $360 \mathrm{Ohm} \mathrm{\textrm {cm } ^ { 2 }}$ after several days of storage. This instability can be addressed by neutralization of the most acidic proton in the polyprotic organic acid with lithium hydroxide. The downside of this approach is the forfeiture of one of the active protons leading to lower cell capacity and formation of solid product earlier during discharge. We found a novel way to adjust $\mathrm{pH}$ without loss of active protons by introduction of imidazole. The reaction of citric acid with imidazole is shown in Fig. 12.

A dramatic improvement in LATP stability was observed for the case where imidazole was added to the citric acid electrolyte (Fig. 13); even after 13 days of immersion, the shape of the impedance plot was almost identical to that observed for a pristine sample. We also determined the anodic stability of imidazole in the potential range selected for Li-Air cell cycling as shown in Fig. 14; the large anodic current observed for the buffer solution corresponds to the oxygen

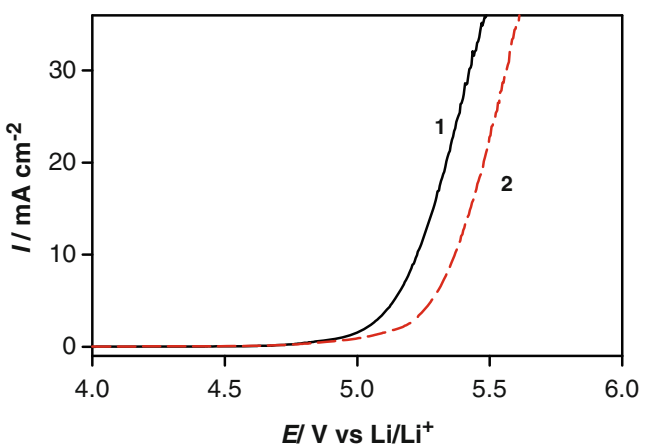

Fig. 14 Anodic stability of imidazole determined by cyclic voltammetry (scan rate of $0.5 \mathrm{mV} / \mathrm{s}$ ) on glassy carbon electrode in electrolytes containing imidazole and phosphate buffer. 1 -buffer solution, $0.71 \mathrm{M}$ $\mathrm{Na}_{2} \mathrm{HPO}_{4}$ and $0.1 \mathrm{M} \mathrm{H}_{3} \mathrm{PO}_{4}, \mathrm{pH}=7 ; 2-0.5 \mathrm{M}$ imidazole, $0.6 \mathrm{M}$ $\mathrm{Na}_{2} \mathrm{HPO}_{4}$, and $0.26 \mathrm{M} \mathrm{H}_{3} \mathrm{PO}_{4}, \mathrm{pH}=7$

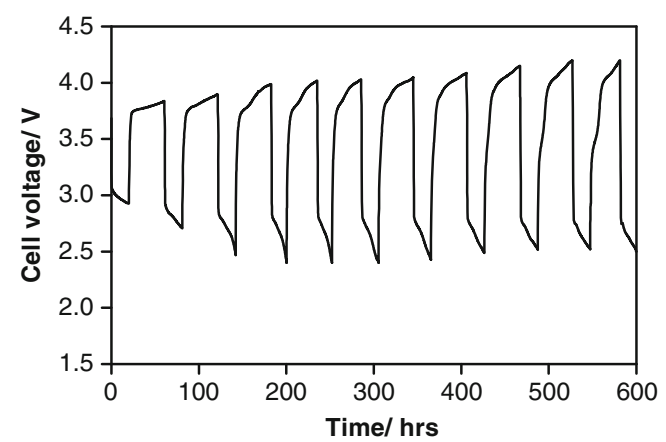

Fig. 15 Cycling performance of aqueous Li-Air cells having an electrolyte based on $2.0 \mathrm{M}$ imidazolium dihydrogen citrate. Discharge rate was $0.5 \mathrm{~mA} / \mathrm{cm}^{2}$. Charge rate was $0.25 \mathrm{~mA} / \mathrm{cm}^{2}$. All discharges lasted $20 \mathrm{~h}$ or were limited by a cutoff voltage of $2.4 \mathrm{~V}$. All charge capacities were equal to the capacities of the discharges immediately preceding them or were limited by a cutoff voltage of $4.2 \mathrm{~V}$

evolution reaction. In Fig. 14, one can see that the anodic process is shifted in the positive direction and no additional electrochemical features are observed, indicating good anodic stability for the imidazole electrolyte.

We then built aqueous Li-Air cells using imidazolium dihydrogen citrate electrolyte in the air cathode. As is shown in Fig. 15, we observed about ten cycles at a current density of $1 \mathrm{~mA} / \mathrm{cm}^{2}$ and an areal capacity of $5 \mathrm{mAh} / \mathrm{cm}^{2}(\mathrm{C} / 5)$ before the air electrode began to polarize. However, we observed

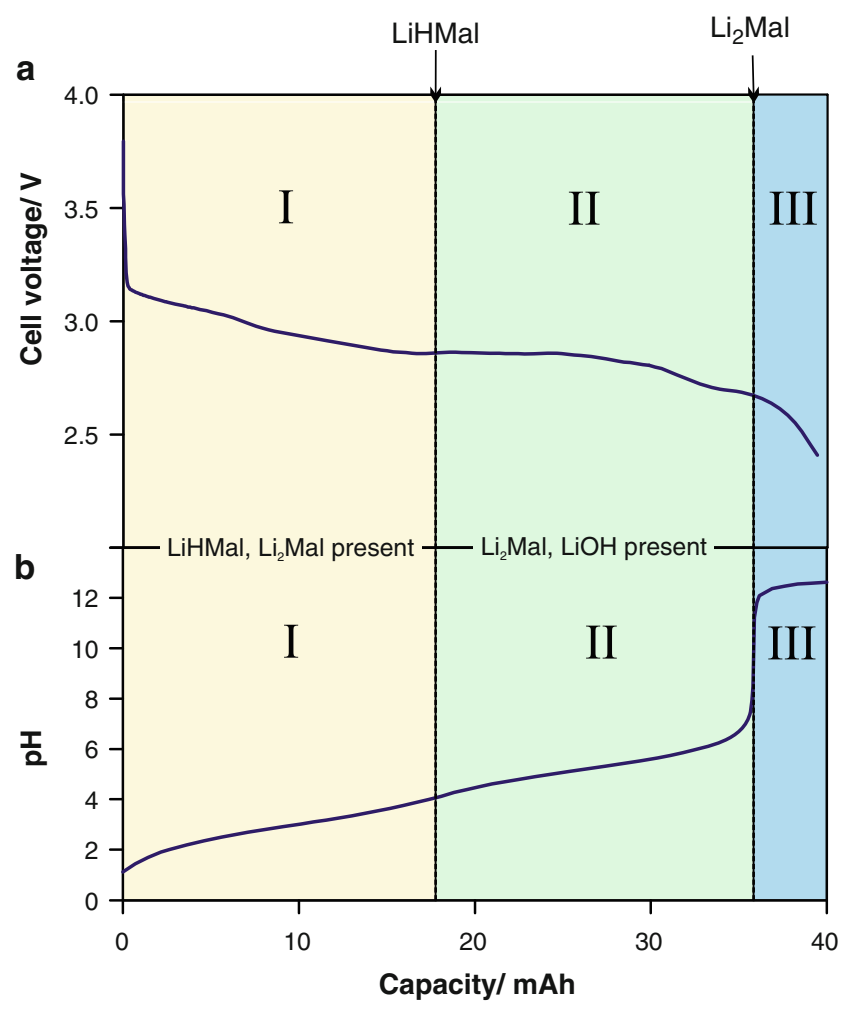

Fig. 16 a Discharge voltage profile of aqueous Li-Air cell having an electrolyte based on 4.0 M malonic acid. b Experimental titration curve for the same electrolyte plotted as a function of cell discharge capacity 
much better cycling behavior for Li-Air cells built with air electrodes having malonic acid electrolyte.

A discharge curve for a Li-Air cell having malonic acid electrolyte is shown in Fig. 16 overlaid with the experimental titration curve for the cell electrolyte re-plotted as a function of capacity (mAh). As can be seen from the data, the $\mathrm{pH}$ of the air electrode varies from about 1 for a fully charged cell to more than 12 for a fully discharged air electrode. As one can see, there are three distinct regions in the $\mathrm{pH}$ curves corresponding to the titration of two active protons, leading finally to a region of high $\mathrm{pH}$. Importantly, using such polyprotic acid-based aqueous electrolytes, we have demonstrated extended cycling for aqueous Li-Air cells. In Fig. 17, we show the cycling behavior for Li-Air cells having malonic acid electrolytes.

For the case of malonic acid, Li-Air cells delivered more than 75 cycles at $5 \mathrm{mAh} / \mathrm{cm}^{2}$ capacity, at discharge current densities of $1 \mathrm{~mA} / \mathrm{cm}^{2}(\mathrm{C} / 5)$, and at charge rates of $0.5 \mathrm{~mA} /$ $\mathrm{cm}^{2}$, for a total cycled capacity of $375 \mathrm{mAh} / \mathrm{cm}^{2}$ ( 75 cycles of $5 \mathrm{mAh} / \mathrm{cm}^{2}$ each). To the best of our knowledge, this is the

a

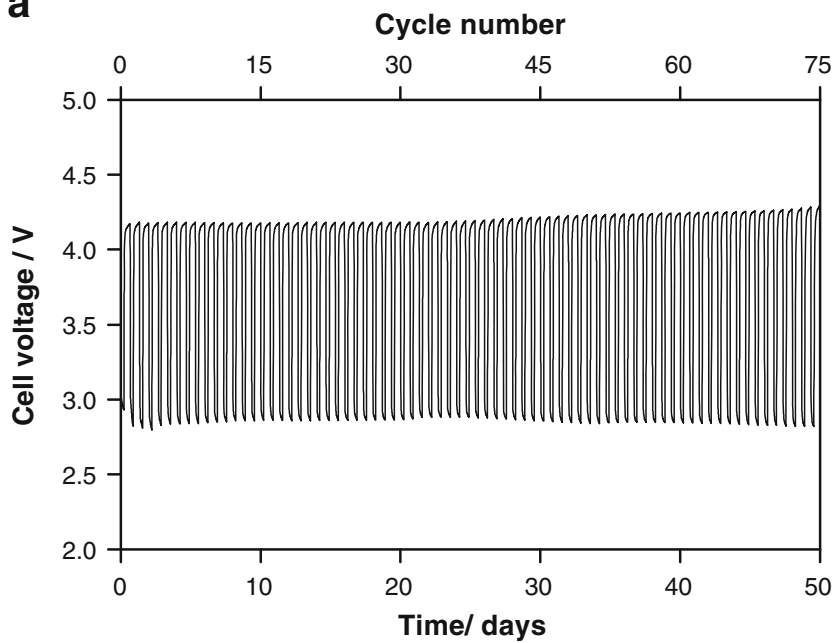

b

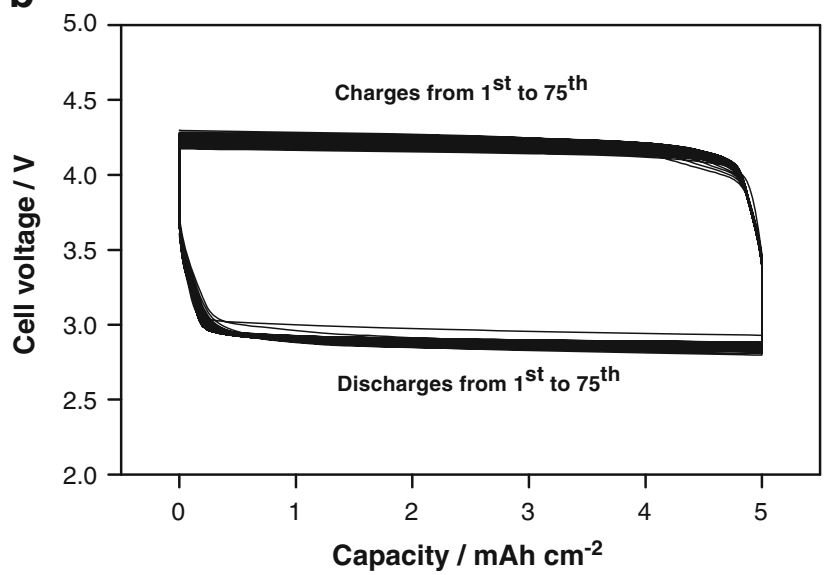

Fig. 17 Cycling behavior of aqueous Li-Air cell having 4.0 M malonic acid electrolyte $\mathbf{a}$ as a function of time and $\mathbf{b}$ as a function of capacity. The cell was discharged at a rate of $1.0 \mathrm{~mA} / \mathrm{cm}^{2}$ for $5 \mathrm{~h}$ and charged at $0.5 \mathrm{~mA} /$ $\mathrm{cm}^{2}$ for $10 \mathrm{~h}$

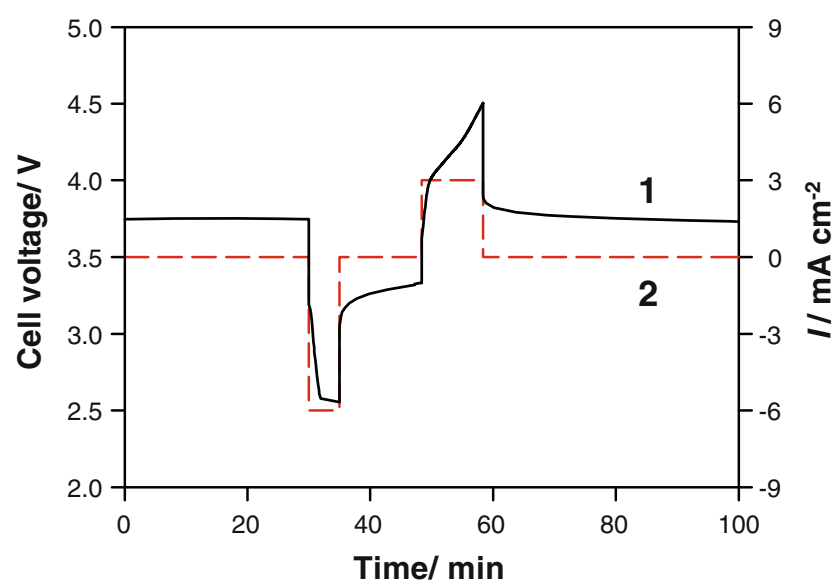

Fig. 18 High-rate pulse behavior of rechargeable aqueous Li-Air cell having $4.0 \mathrm{M}$ malonic acid electrolyte. The cell was discharged at a rate of $6.0 \mathrm{~mA} / \mathrm{cm}^{2}$ for $5 \mathrm{~min}$ and charged at $3.0 \mathrm{~mA} / \mathrm{cm}^{2}$ for $10 \mathrm{~min}$. 1 -cell voltage, 2 - current density

largest cycled capacity ever reported for Li-Air chemistry. Aqueous Li-Air cells having malonic acid electrolyte also demonstrate reasonably good high current pulse behavior as can be seen from Fig. 18. We believe that the present limitation to cycling of aqueous rechargeable Li-Air might be mediated through better management of the water balance between the air electrode and the external environment.

\section{Conclusions}

Lithium-air chemistry offers the potential for unprecedented energy density and a step change relative to existing commercial batteries. In our opinion, the use of a PLE is a basic requirement for both nonaqueous and aqueous Li-Air technologies. In all cases, the use of a PLE leads to a self-discharge rate of effectively zero. For aqueous Li-Air, the need for a PLE is obvious. However, even for nonaqueous Li-Air, it appears that the use of a PLE could be necessary to enable the use of electrolytes stable to lithium peroxide and superoxide but not lithium metal and to protect the negative electrode from reaction with moisture in ambient air. Nonaqueous Li-Air chemistry is clearly plagued by a number of complex technical hurdles as discussed above. The situation with rechargeable aqueous Li-Air cells is much better. We have demonstrated good cycling at reasonable current densities (C/5 discharge) and high current densities for short bursts $(>\mathrm{C}$ rate for $5 \mathrm{~min}$ ). We have also demonstrated that primary aqueous $\mathrm{Li}$-Air batteries can achieve spectacular specific energies of over $800 \mathrm{Wh} / \mathrm{kg}$.

Acknowledgments This work was funded in part by the ARPA-E of the U.S. Department of Energy and by the U.S. Army CERDEC. The authors also acknowledge the participation of V. Loginova in the experimental work and helpful discussions with Dr. P.N. Ross of the Lawrence Berkeley National Laboratory in Berkeley, CA. 
Open AccessThis article is distributed under the terms of the Creative Commons Attribution License which permits any use, distribution, and reproduction in any medium, provided the original author(s) and the source are credited.

\section{References}

1. Visco SJ, Nimon E, De Jonghe LC (2009) In: Garche J (ed) Encyclopedia of electrochemical power sources. Elsevier, Amsterdam 4:376

2. Nimon YS, Visco SJ (2010) US Patent 7645543, filed Feb 3, 2004

3. Visco SJ, Katz BD, Nimon YS (2007) US Patent 7282295, filed Apr 14,2004

4. Visco SJ, Nimon YS, Katz BD (2007) US Patent 7282296, filed Oct 14,2003

5. Visco SJ, Nimon YS, Katz BD, Petrov A (2010) US Patent 7824806 , filed Aug 8, 2006

6. Bruce PG, Freunberger SA, Hardwick LJ, Tarascon JM (2012) Nat Mat 11:19

7. Christiansen J, Albertus P, Sanchez-Carrera RS, Lohmann T, Kozinsky B, Leidtke R, Ahmed J, Kojic A (2012) J Electrochem Soc 159:R1-R30

8. Peng Z, Freunberger SA, Chen Y, Bruce PG (2012) Science 337: 563-566

9. Walker W, Giordani V, Uddin J, Bryantsev VS, Chase GV, Addison D (2013) J Am Chem Soc 135:2076-2079

10. Visco SJ, Nimon E, Katz BD, De Jonghe LC, Chu MY (2004) In: Abstr Int Meet Lithium Batt. Nara, Japan, 53

11. Visco SJ, Nimon E, Katz BD, De Jonghe LC, Chu MY (2004) In: Abstr Int Meet Lithium Batt. Nara, Japan 396

12. Visco SJ, Nimon E (2004) In: Abstr Int Meet Lithium Batt. Nara, Japan 397

13. Goodenough JB, Hong HYP, Kafalas JA (1976) Mater Res Bull 11: 203-220

14. Abraham KM, Jiang Z (1996) J Electrochem Soc 143:1-5

15. Aurbach D, Daroux M, Faguy P, Yeager E (1991) J Electroanal Chem 297:225-244

16. Mizuno F, Nakanishi S, Kotani Y, Yokoishi S, Iba H (2010) Electrochemistry 78:403-405

17. Freunberger SA, Peng Z, Hardwick LJ, Chen Y, Barde F, Bruce PG (2010) In: Proc 218th Electrochem Soc Meet, Las Vegas, Nevada

18. McCloskey BD, Bethune DS, Shelby RM, Girishkumar G, Luntz AC (2011) J Phys Chem Lett 2:1161-1166

19. Visco SJ, Nimon YS (2007) US Patent Application 20070117007, filed Nov 22, 2006
20. Dresser KJ, Prince RN (1969) NASA Contractor report In: Thermophys. Conf. Am. Inst. Aeronaut. San-Francisco, USA

21. Maricle DL, Hodgson WG (1965) Anal Chem 37:1562-1565

22. Peover ME, White BS (1966) Electrochim Acta 11:1061-1067

23. Jain PS, Lal S (1982) Electrochim Acta 27:759-763

24. Bryantsev VS, Uddin J, Giordani V, Walker W, Addison D, Chase GV (2013) J Electrochem Soc 160:A160-A171

25. Xie B, Lee HS, Li H, Yang XQ, McBreen J, Chen LQ (2008) Electrochem Commun 10:1195-1197

26. Li LF, Xie B, Lee HS, Li H, Yang XQ, McBreen J, Huang XJ (2009) J Power Sources 189:539-542

27. Shanmukaraj D, Grugeon S, Gachot G, Laruelle S, Mathiron D, Tarascon JM, Armand M (2010) J Am Chem Soc 132: 3055-3062

28. Mitchell RR, Gallant BM, Shao-Horn Y, Thompson CV (2013) J Phys Chem Lett 4:1060-1064

29. Lee JH, Black R, Popov G, Pomerantseva E, Nan F, Botton G, Nazar LF (2012) Energy Environ Sci 5:9558-9565

30. Lu YC, Gallant BM, Kwabi DG, Harding JR, Mitchell RR, Whittingham MS, Shao-Horn Y (2013) Energy Environ Sci 6:750768

31. Nimon VY, Visco SJ, De Jonghe LC, Volfkovich YM, Bograchev DA (2013) ECS Electrochem Lett 2:A33-A35

32. McCloskey BD, Speidel A, Scheffler R, Miller DC, Viswanathan V, Hummelshøj JS, Nørskov JK, Luntz AC (2012) J Phys Chem Lett 3: 997-1001

33. Watanabe Y, Kinoshita S, Wada S, Hoshino K, Morimoto H, Tobishima S (2008) J Power Sources 179:770-779

34. Jung HG, Hassoun J, Park JB, Sun YK, Scrosati B (2012) Nat Chem 4:579-585

35. Fu J (1997) Solid State Ionics 96:195-200

36. Fu J (1997) J Am Ceram Soc 80:1901-1903

37. Birke P, Salam F, Döring S, Weppner W (1999) Solid State Ionics 118:149-157

38. West WC, Whitacre JF, Lim JR (2004) J Power Sources 126: 134-138

39. Puech L, Cantau C, Vinatier P, Toussaint G, Stevens P (2012) J Power Sources 214:330-336

40. Visco SJ, De Jonghe LC, Nimon YS, Petrov A, Pridatko K (2012) US Patent 8323820, filed Jun 12, 2009

41. Visco SJ, De Jonghe LC, Nimon YS, Petrov A, Pridatko K (2013) US Patent 8455131, filed Jun 12, 2009

42. Visco SJ, De Jonghe LC, Nimon YS, Petrov A, Pridatko K (2013) US Patent 8389147, filed Jun 12, 2009

43. Visco SJ, Nimon YS, De Jonghe LC, Petrov A, Goncharenko N (2013) US Patent Application 20130045428, filed Aug 17, 2012 